\title{
Lifun og dánarorsakir barna sem greindust með krabbamein á Íslandi 1981-2006
}

Trausti Óskarsson ${ }^{1}$ læknir

Ólafur Gísli

Jónsson ${ }^{1,2}$

barnalæknir

Jón $\mathbf{R}$.

Kristinsson ${ }^{1,2}$

barnalæknir

Guð̆mundur K. Jónmundsson ${ }^{1,2}$ barnalæknir

\section{Jón Gunnlaugur Jónasson ${ }^{2,3,4}$ meinafræðingur} Ásgeir Haraldsson $^{1,2}$ barnalæknir

Lykilorð: börn, krabbamein, faraldsfræði, lifun.

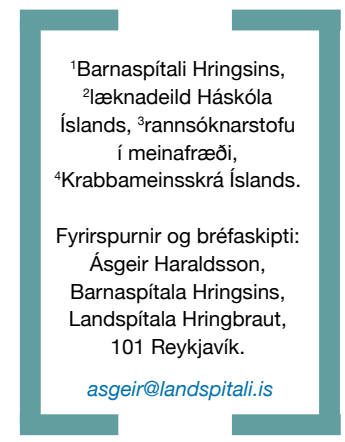

\section{Ágrip}

Inngangur: Um fjórðungur barna sem greinist með krabbamein deyr vegna sjúkdóms síns eða meðferðartengdra fylgikvilla. Tilgangur rannsóknarinnar var að kanna lifun og dánarorsakir barna sem greinst hafa með krabbamein á Íslandi. Aðferðir: Rannsóknin var afturskyggn, lýðgrunduð og náði til allra einstaklinga yngri en 18 ára sem greindust með krabbamein á Íslandi frá upphafi árs 1981 til loka ársins 2006. Upplýsingum var safnað frá Krabbameinsskrá Íslands, sjúkraskrám og Hagstofu Íslands.

Niðurstöður: Á rannsóknartímabilinu greindust 279 börn með krabbamein á Íslandi. Af peim voru 215 á lífi í lok árs 2008. Á tímabilinu var fimm ára lifun 81,2\% og 10 ára lifun 76,7\%. Ekki var marktækur munur á lifun milli kynja, greiningartímabila, aldurs eða búsetu. Gæti pað skýrst af smæð pýðisins. Lifun var mismunandi eftir krabbameinstegundum. Ellefu einstaklingar greindust síðar með meðferðartengd krabbamein, átta peirra létust. Sextán peirra 64 sem létust voru í læknandi meðferð fram að andláti. Var dánarorsök meðferðartengdir fylgikvillar hjá 12 úr peim hópi. Ályktun: Horfur barna og unglinga á Íslandi með krabbamein eru sambærilegar við önnur vestræn ríki. Horfur eru mun verri í meðferðartengdum krabbameinum samanborið við frumkrabbamein. Meðferðartengdir fylgikvillar eru algengasta dánarorsök ef krabbameinsmeðferð er gefin með læknanlegum tilgangi.

\section{Inngangur}

Hjá vestrænum pjóðum er krabbamein algengasta sjúkdómstengda dánarorsökin hjá börnum eftir fyrsta aldursárið. ${ }^{1,2}$ Á Íslandi er árlegt aldursstaðlað nýgengi 14,5 af 100.000 börnum yngri en 18 ára og hefur pað ekki breyst á síðustu premur áratugum. ${ }^{3}$

Árangur krabbameinsmeðferðar hjá börnum er ein af velgengnisögum nútímalæknisfræði. Framfarir í krabbameinsmeðferð voru miklar á sjötta og sjöunda áratugnum en á peim tíma jókst lifun hjá pessum börnum úr um 35\% upp í allt að 70\%. ${ }^{4}$ Munaði par mest um bætta meðferð við hvítblæði. Pennan góða árangur má fyrst og fremst pakka framförum í krabbameinslyfjameðferð, beinmergsskiptum og bættri stuðningsmeðferð. ${ }^{5}$ Talið er að um 75\% barna sem greinast með krabbamein á Vesturlöndum læknist nú af peim. ${ }^{6}$ Árangur á Norðurlöndunum, par með talið á Íslandi, hefur á undanförnum árum verið með pví besta sem pekkist í heiminum. ${ }^{7}$

Horfur eru mjög mismunandi eftir tegund krabbameins. Rákvöðvasarkmein (rhabdomyosarcoma), taugakímfrumnaæxli (neuroblastoma) og heilastofnsæxli (brain stem glioma) hafa til dæmis mun verri horfur en bráðaeitilfrumuhvítblæði (acute lymphoblastic leukemia), lággráðu stjarnfrumnaæxli (low grade astrocytoma) í heilahveli og sjónkímfrumnaæxli (retinoblastoma). ${ }^{6,8}$ Að auki fer pað eftir vefjafræðilegri stigun, dreifingu og áhættustigi krabbameinsins hverjar horfurnar eru. ${ }^{9}$

Ástæður pess að börn látast úr krabbameini eru mismunandi, allt frá beinum áhrifum krabbameinsins, eins og æxlisvaxtar í heila eða brjóstholi, eða meðferðartengdar ástæður eins og sýkingar og blæðingar. Andlát á fyrstu 30 dögum eftir greiningu eru sjaldgæf nú orðið en dæmi eru um að börn greinist með krabbamein skömmu fyrir eða jafnvel eftir andlát. ${ }^{10}$ Helstu orsakir fyrir snemmkomnu andláti eru sýkingar, blæðingar og aukaverkanir meðferðar. ${ }^{11,12}$

Langvinnir fylgikvillar krabbameinsmeðferðar í æsku eru algengir. ${ }^{13-15}$ Meðferðartengd krabbamein eru meðal peirra alvarlegustu og geta komið upp mörgum árum eftir að krabbameinsmeðferð lýkur. ${ }^{16-19}$ Algengustu tegundir meðferðartengdra krabbameina sem greinast á barnsaldri eru bráðamergfrumuhvítblæði (acute myeloid leukemia), sarkmein í beinum og mjúkvefjum og miðtaugakerfisæxli, en ef meðferðartengd krabbamein greinast á fullorðinsaldri eru brjóstakrabbamein og skjaldkirtilskrabbamein algengust. ${ }^{16,20}$ Horfur meðferðartengdra krabbameina hjá börnum eru mun verri en frumkrabbameina og eru pau algengasta sjúkdómstengda dánarorsökin hjá pessum hópi. ${ }^{18,21}$

Áður hafa greinarhöfundar birt rannsókn á nýgengi krabbameina hjá börnum á Íslandi. ${ }^{3}$ Markmið pessarar rannsóknar var að kanna 


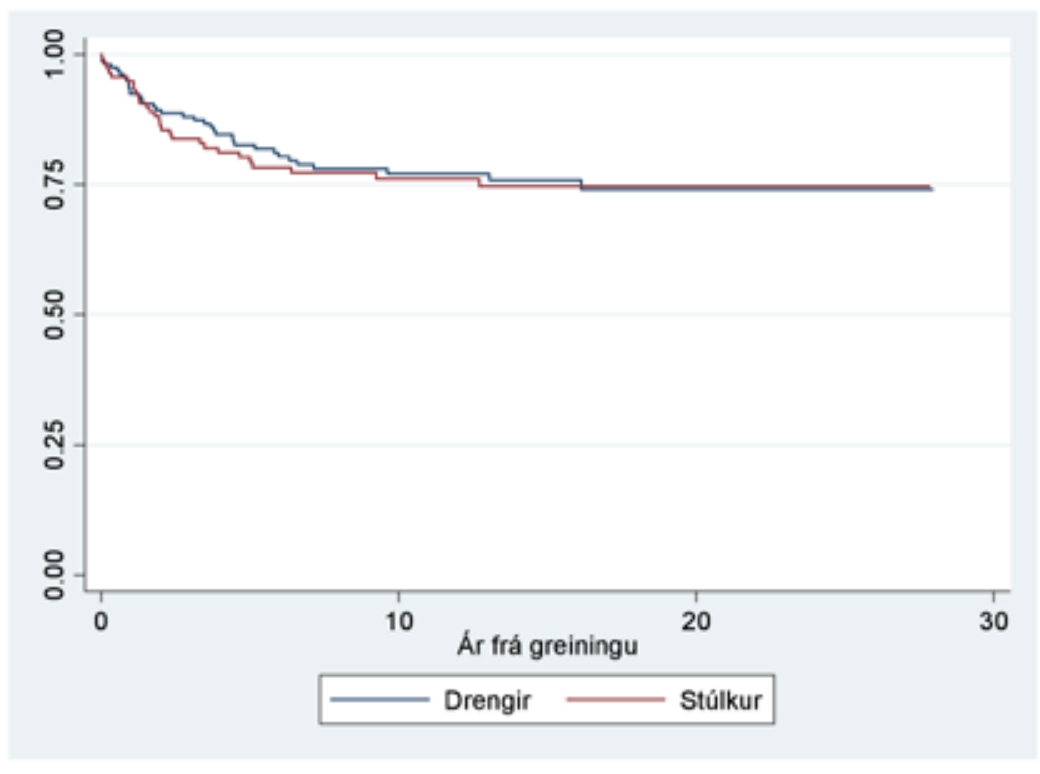

Mynd 1. Kynjaskipt heildarlifun hjá 279 börnum yngri en 18 ára (159 drengjum og 120 stúlkum) sem greindust með krabbamein á árunum 1981$2006(p=0,8174)$ lifun og dánarorsakir barna sem greinst hafa með krabbamein á Íslandi, en ítarleg rannsókn af pví tagi hefur ekki birst áður. Nákvæmar upplýsingar eru ekki einungis mikilvægar fyrir samanburð við önnur lönd, heldur einnig fyrir meðferð og rannsóknir sem stuðla að bættri lifun pessa sjúklingahóps.

\section{Aơferöir}

Rannsóknin var afturskyggn og lýðgrunduð. Öll krabbameinstilfelli sem greind hafa verið hjá

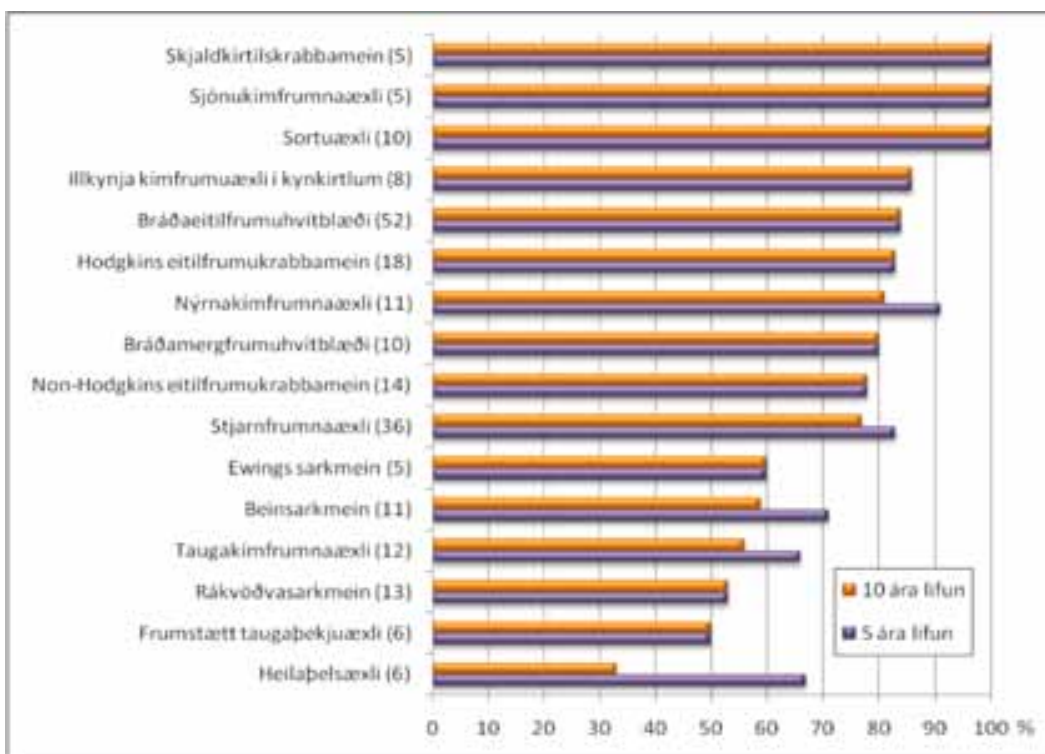

Mynd 2. Fimm og tíu ára lifun eftir algengustu krabbameinstegundunum. Í sviga er fjöldi greindra tilfella á rannsóknartímabilinu. Sjónkímfrumnaæxli (retinoblastoma), illkynja kimfrumuæxli í kynkirtlum (malignant gonadal germ-cell tumor), nýrnakímfrumnaæxli (nephroblastoma, Wilms tumor), stjarnfrumnaxxli (astrocytoma,

WHO gr. 1-4), taugakímfrumnaæxli (neuroblastoma), rákvöđvasarkmein (rhabdomyosarcoma), frumstrett taugapekjuæxli (primitive neuroectodermal tumor, PNET), heilapelsæxli (ependymoma). einstaklingum yngri en 18 ára og tilkynnt hafa verið til Krabbameinsskrár Íslands frá 1.1.198131.12.2006 voru skráð í gagnagrunn (File Maker Pro 8.0) sem hannaður var af rannsakendum. Nánari upplýsingar voru fengnar úr sjúkraskrám Landspítala, Barnaspítala Hringsins og Sjúkrahússins á Akureyri. Upplýsingar um meðferðartengd krabbamein fengust frá Krabbameinsskrá Íslands og sjúkraskrám og voru pau tilfelli skráð sem greindust fyrir lok árs 2008. Upplýsingar um lifun voru bornar saman við gögn frá Pjóðskrá og var miðað við lifun fram til 31.12.2008.

Eftirfarandi breytur voru skráðar í gagnagrunninn: Aldur, kyn, búseta við greiningu, aldur við greiningu, pekktir erfðafræðilegir áhættupættir, krabbameinsgreining, endurkoma meins, dreifing meins, dánardagsetning, dánarstaðsetning og dánarorsök. Tilvik voru flokkuð samkvæmt ICCC-3 flokkunarkerfinu (International Classification of Childhood Cancer, 3. útgáfu $)^{22}$ og pví hvort pau voru frumkrabbamein (primary neoplasm), endurkomin frumkrabbamein (relapse, recidive) eða meðferðartengd krabbamein (secondary neoplasm). Við samanburð á greiningarárum var greiningartímabilunum skipt í tvennt, 1981-1993 og 1994-2006. Samanburður á aldri miðaðist við aldursbilin 0-4 ára, 5-9 ára, 10-14 ára og 15-17 ára. Búsetu var skipt milli höfuðborgarsvæðisins og landsbyggðarinnar. Upplýsingar um dánarorsakir voru fundnar í sjúkraskrám og krufningarskýrslum ef krufning átti sér stað. Dánarorsakir voru flokkaðar í fjóra flokka: Sýking, heilablæðing, æxlisvöxtur og annað. Dánarstaðsetningar peirra sem voru í læknandi meðferð voru flokkaðar í prjá flokka: Gjörgæsludeild, sjúkradeild og meðferð erlendis. Ef einstaklingur var í meðferð með læknanlegum tilgangi við andlát var hún skilgreind sem læknandi meðferð, annars var um líknandi meðferð að ræða.

Kaplan-Meier-aðferð var notuð til að reikna út lifun og við samanburð á marktækni milli valinna breyta var miðað við öryggismörk (confidence interval) 95\% og log-rank test með p-gildi $<0,05$. Lifunarútreikningar miðuðust við frumkrabbamein og pví voru meðferðartengd krabbamein ekki tekin með í pá útreikninga.

Fengið var leyfi frá lækningaforstjóra Landspítala, Persónuvernd (tilvísunarnúmer: 2007 100755), siðanefnd Landspítala, vísindasiðanefnd heilbrigðisráðuneytisins (tilvísunarnúmer: VSNb2008090009) og yfirlækni Krabbameinsskrár Íslands. 


\section{Niðurstöður}

Á tímabilinu frá 01.01.1981 til 31.12.2006 greindust 279 börn með frumkrabbamein á Íslandi, af peim voru 215 á lífi í lok árs 2008. Allir peir sem létust, létust af völdum krabbameinsins eða meðferðartengdra fylgikvilla. Á mynd 1 sést Kaplan-Meier lifunarlínurit fyrir bæði drengi og stúlkur sem greindust með krabbamein á tímabilinu. Fimm ára lifun var 81,2\% (öryggismörk $76,1-85,4 \%)$; drengir $82,7 \%$ (75,8-87,8\%), stúlkur $79,3 \%(70,7-85,6 \%)$, en 10 ára lifun 76,7\% (71,1$81,4 \%)$; drengir $77,1 \%(69,4-83,1 \%)$, stúlkur $76,1 \%$ $(67,1-83,0 \%)$. Ekki reyndist vera marktækur munur á fimm eða tíu ára lifun milli kynja, tímabilanna 1981-1993 og 1994-2006, búsetu við greiningu, eða aldurshópanna 0-4 ára, 5-9 ára, 10-14 ára og 15-17 ára. Pegar borin var saman lifun í premur stærstu ICCC-3 flokkunum, I. Hvítblæði, II. Eitilfrumukrabbamein, III. Miðtaugakerfisæxli, var munurinn ekki marktækur.

Á mynd 2 má sjá fimm og tíu ára lifun eftir peim krabbameinstegundum sem fimm eða fleiri börn greindust með (alls 222 börn). Ekki voru gerðir samanburðarútreikningar par sem um lítið pýði var að ræða.

Af 279 börnum sem greindust með frumkrabbamein á árunum 1981-2006 höfðu 11 greinst með meðferðartengd krabbamein fyrir lok árs 2008, átta peirra létust (tafla I). Á pessu tímabili greindust tveir einstaklingar með tvö meðferðartengd krabbamein. Báđir létust. Tíminn frá greiningu frumkrabbameins til greiningar meðferðartengds krabbameins var frá 2,0 árum til 12,6 ára (miðgildi 5,4 ár). Enginn peirra sem greindist með meðferðartengt krabbamein hafði fyrirfram pekktan erfðafræðilegan áhættupátt eins og Fanconi-blóðleysi og taugatrefjaæxlager (neurofibromatosis).

Af peim 64 sem létust voru 24 með frumkrabbamein sem ekki hafði tekist að lækna, 32 með endurkomu meins og átta með meðferðartengd krabbamein. Sá yngsti sem lést var tveggja mánaða og sá elsti 30 ára og fjögurra mánaða. Fjögur börn létust af völdum frumkrabbameina á fyrstu 30 dögum meðferðarinnar, par af eitt á greiningardaginn.

Sextán voru ílæknandi meðferð og 45 ílíknandi meðferð við andlát. Einn lést áður en meðferð hófst og ekki fundust upplýsingar um meðferð hjá tveimur einstaklingum, annar peirra var með frumkrabbamein en hinn var með meðferðartengt krabbamein. Fleiri fengu læknandi meðferð ef um var að ræða frumkrabbamein (sjö af 24) og meðferðartengd krabbamein (prír af átta) heldur en ef um endurkomu meins var að ræða (sex af 32).
Tafla I. Fjöldi sjúklinga sem greindust með meðferðartengd krabbamein. Tími i árum frá greiningu frumkrabbameins til greiningar meðferðartengds krabbameins. Afdrif i lok árs 2008. 'Tími frá greiningu frumkrabbameins til greiningar annars meðferðartengds krabbameins. ${ }^{2}$ Myelodysplasia, ${ }^{3}$ medulloblastoma, ${ }^{4}$ rhabdomyosarcoma, ${ }^{5}$ astrocytoma, ${ }^{6}$ synovial sarcoma, ${ }^{7}$ ependymoma, ${ }^{8}$ primitive neuroectodermal tumor (PNET), ${ }^{9}$ atypical meningioma.

\begin{tabular}{|c|c|c|c|c|}
\hline Tilfelli & Frumkrabbamein (A) & Meðferðartengt krabbamein (B) & $\begin{array}{l}\text { Tími frá } \\
\text { A til B (ár) }\end{array}$ & Á lífi \\
\hline 1 & $\begin{array}{l}\text { Lymfoblastískt } \\
\text { eitilfrumukrabbamein }\end{array}$ & Mergmisproski $^{2}$ & 3,0 & Nei \\
\hline 2 & $\begin{array}{l}\text { Langvinnt } \\
\text { mergfrumuhvítblæði }\end{array}$ & Bráđahvítblæði & 5,4 & Nei \\
\hline \multirow[t]{2}{*}{3} & \multirow{2}{*}{ Mænukímfrumnaæxli³ } & Mergmisproski & 2,0 & \\
\hline & & Bráđamergfrumuhvítblæði & $2,9^{1}$ & Nei \\
\hline 4 & Bráđaeitilfrumuhvítblæði & Bráđamergfrumuhvítblæði & 4,4 & Nei \\
\hline 5 & Rákvöðvasarkmein ${ }^{4}$ & Stjarnfrumnaæxli (WHO gr. 4) & 6,9 & Nei \\
\hline 6 & Stjarnfrumnaæxli ${ }^{5}$ (WHO gr. 2) & Stjarnfrumnaæxli (WHO gr. 4) & 2,4 & Já \\
\hline 7 & Bráðaeitilfrumuhvítblæði & Mjúkvefjasarkmein í liðslímu & 10,7 & Já \\
\hline 8 & Ewings sarkmein & Beinsarkmein & 6,0 & Já \\
\hline \multirow[t]{2}{*}{9} & \multirow{2}{*}{ Heilapelsæxli } & Beinsarkmein & 6,7 & \\
\hline & & Bráđamergfrumuhvítblæði & $9,6^{1}$ & Nei \\
\hline 10 & Frumstætt taugapekjuæxli & Atýpískt heilahimnuæxli9 & 12,6 & Nei \\
\hline 11 & $\begin{array}{l}\text { Hodgkins } \\
\text { eitilfrumukrabbamein }\end{array}$ & Bráđamergfrumuhvítblæði & 2,5 & Nei \\
\hline
\end{tabular}

Níu af 16 sem fengu læknandi meðferð voru með hvítblæði, fjórir með æxli í miðtaugakerfi og fjórir með illkynja æxli utan miðtaugakerfis (tafla II). Algengasta dánarorsökin var sýking (átta af 16). Í sjö tilfellum af átta var um öndunarfærasýkingu að ræða en í einu tilfelli var pað blóðsýking. Í tveimur tilvikum var um heilablæðingu að ræða og voru báðir með beinmergsbælingu af völdum hvítblæðismeðferðar. Hjá peim fjórum sem létust af völdum heilaæxlis var dánarorsökin ífarandi vöxtur heilaæxlis sem svaraði ekki meðferð. Tólf af pessum 16 einstaklingum voru á gjörgæsludeild við andlát. Prír peirra voru í meðferð erlendis og létust peir allir úr sýkingum, tveir voru í beinmergsskiptum og einn í Extracorporeal Membrane Oxygenation (ECMO) vegna alvarlegrar öndunarfærasýkingar. Hjá öllum fjórum sem létust á sjúkradeild bar andlát brátt að.

Fjörutíu og fimm einstaklingar voru í líknandi meðferð við andlát, 15 með heilaæxli, 26 með illkynja æxli utan miðtaugakerfis og fjórir

Tafla II. Dánarorsakir einstaklinga sem voru í læknandi meðferð við andlát eftir krabbameinsflokkum. ${ }^{1}$ AExlisrek til lungna í aðgerð og fjölliffærakerfabilun í kjölfar venoocclusive disease.

\begin{tabular}{lccccc}
\hline Krabbamein & Alls & Sýking & Heilablæðing & Æxlisvöxtur & Annað \\
\hline Hvítblæði & 8 & 6 & 2 & - & - \\
\hline Æxli í miðtaugakerfi & 4 & - & - & 4 & - \\
\hline ÆExli utan miðtaugakerfis & 4 & 2 & - & - & $2^{1}$ \\
\hline Alls & 16 & 8 & 2 & 4 & 2 \\
\hline
\end{tabular}


með hvítblæði. Ekki reyndist unnt að greina nákvæmlega dánarorsök hjá öllum sem voru í líknandi meðferð par sem pær upplýsingar vantaði í sjúkraskrár. Hins vegar fundust fullnægjandi upplýsingar um dánarorsakir peirra fjögurra sem voru í líknandi meðferð vegna hvítblæðis, sýking í tveimur tilvikum, blæðing í meltingarveg og krampi á grunni útsæðis í miðtaugakerfi. Af 26 einstaklingum sem voru með æxli utan miðtaugakerfis voru 20 með meinvörp við andlát.

\section{Umræða}

Um prjú af hverjum fjórum börnum sem greindust með krabbamein á Íslandi á árunum 1981-2006 voru lifandi í lok árs 2008. Fimm ára lifun var $81,2 \%$ og 10 ára lifun $76,7 \%$. Borið saman við önnur vestræn ríki er árangurinn á Íslandi sambærilegur., 8, 23 Áður hafa rannsakendur sýnt að ekki var munur á heildarnýgengi eftir kynjum, greiningarárum, aldri eða búsetu á Íslandi. ${ }^{3}$ Ekki var heldur marktækur munur pegar pessar breytur voru athugaðar með tilliti til lifunar. Ástæða pess að ekki fannst marktækur munur á ofangreindum breytum gæti verið smæð pýðisins. Erlendar rannsóknir hafa sýnt að ekki er munur á heildarlifun milli kynja en hins vegar hafa börn sem greinast með krabbamein á fyrsta aldursári verri horfur en pau sem eldri eru. ${ }^{2}$ Einnig hefur komið í ljós að lifun hefur aukist smám saman á undanförnum premur áratugum. ${ }^{8}$

Ekki kom á óvart að lifun var ólík eftir krabbameinstegundum og var hlutfallið að mestu í takt við niðurstöður erlendra rannsókna. ${ }^{4,23}$ Pótt samanburður á lifun einstakra meina í pessari rannsókn takmarkist við pann fjölda sem liggur á bak við hvert mein, gefur hann hugmynd um hve mismunandi horfurnar geta verið við greiningu.

Við faraldsfræðilegar rannsóknir á sjaldgæfum sjúkdómum í fámennum samfélögum eins og Íslandi er mikilvægt að rannsóknartímabilið sé langt, vegna tilviljanasveiflna í nýgengi og lifun. Rannsókn okkar náði yfir 26 ára tímabil til pess að mæta breytileika í lifunarútreikningum.

Ekkert barnanna í rannsókninni lést úr öðrum sjúkdómum en krabbameinum og gerir pað hana og ályktanir sem unnt er að draga varðandi lifun áreiðanlegri. Að auki telst pað styrkleiki að rannsóknin var lýðgrunduð og að upplýsingar um meðferð og afdrif sjúklinga fengust úr sjúkraskrám sem yfirfarnar voru af rannsakendum. Veikleikar rannsóknarinnar voru fyrst og fremst smæð pýðisins og stuttur eftirfylgdartími peirra sem greindust á síðari hluta rannsóknartímabilsins. Að auki fundust ekki upplýsingar um dánarorsakir hjá öllum sem voru í líknandi meðferð við andlát. Ákveðið var í upphafi að styðjast ekki við upplýsingar um dánarorsakir úr dánarvottorðum par sem rannsakendur töldu að ítarlegri upplýsingar væri að finna í sjúkraskrám og krufningaskýrslum. Aðeins fundust upplýsingar um dánarorsakir í sjúkraskrám hjá hluta peirra sjúklinga sem voru í líknandi meðferð en með pví að nota dánarvottorð hefði verið hægt að fá upplýsingar um dánarorsakir hjá peim hópi. Mikilvægari eru pó upplýsingar um dánarorsakir peirra sem voru ílæknandi meðferð, par sem bætt lifun felst meðal annars í pví að fyrirbyggja dauðsföll á meðan meðferð stendur yfir.

Við greiningu illkynja æxla hjá börnum eru pau oftar á hærri stigum og útbreiddari en hjá fullorðnum, en fimm ára lifun hjá fullorðnum er samt sem áður verri, eða 60-65\%. ${ }^{8}{ }^{24}$ Börn svara krabbameinslyfjameðferð almennt betur en fullorðnir pví frumufjölgun er meiri og frumurnar pví næmari fyrir verkun lyfjanna. Á hinn bóginn eru aðrar frumur einnig næmari fyrir lyfjunum og pví eru varanleg áhrif og líkur á síðkomnum fylgikvillum og meðferðartengdum krabbameinum meiri. ${ }^{25}$ Sláandi var að átta af ellefu einstaklingum sem greindust með meðferðartengd krabbamein létust. Lifun hjá einstaklingum með meðferðartengd krabbamein er pví mun verri en pegar um frumkrabbamein er að ræða. Ástæður pess geta meðal annars verið аð pau eru oft af tegundum sem almennt hafa verri horfur. ${ }^{21,26}$ Að auki geta pessir einstaklingar verið með erfðatengda áhættupætti fyrir krabbameinsmyndun sem gera heilbrigðar frumur næmari fyrir skaðlegum áhrifum geisla og ákveðinna krabbameinslyfja. ${ }^{27}$ Ekki er hægt að fullyrða að öll meðferðartengdu krabbameinin hafi orsakast af yfirgenginni krabbameinsmeðferð, til dæmis er mögulegt að um sé að ræða tvö frumkrabbamein óháð meðferð, eða að frumkrabbameinið hafi legið í dvala og síðan umbreyst í meira illkynja krabbamein, eins í tilfellum tvö og sex í töflu I.

Börn sem greinast með krabbamein fá oft mjög punga meðferð sem getur haft ýmsar bráðar aukaverkanir í för með sér, eins og til dæmis hvítkornafæð og blóðflögufæð. Hvítkornafæð eykur til muna hættuna á alvarlegum sýkingum en alvarlegar blæðingar sökum blóðflögufæðar eða storkutruflana eru sjaldgæfar. ${ }^{28}$ Sextán af 64 einstaklingum voru í læknandi meðferð pegar andlát bar að. Flestir peirra létust af völdum sýkinga eða blæðinga sem rekja má til meðferðartengdrar beinmergsbælingar. Мeð framförum í greiningu og meðhöndlun meðferðartengdra fylgikvilla væri hægt að draga úr 
dánartíðni af pessum orsökum og auka pannig lifun enn frekar.

Miklar framfarir voru í krabbameinslækningum fram á áttunda áratuginn en á síðustu premur áratugum hefur hægt á framförum, pótt stöðugt sé verið að próa nýja meðferðarmöguleika. Uppistaðan í flestum krabbameinslyfjameðferðum byggist enn á lyfjum sem próuð voru fyrir sjöunda áratuginn. Framfarir síðustu ára hafa almennt falist í aðlögun meðferðarskammta, samspili lyfja og bættri stuðningsmeðferð.

Pó horfur séu almennt góðar hjá börnum sem greinast með krabbamein er enn langt í land að allir læknist. Меð bættri meðferð og nákvæmu eftirliti með tilliti til endurkomu meins og meðferðartengdra krabbameina verður vonandi hægt að gera enn betur. Líklegt er að krabbameinsmeðferð framtíðarinnar verði sniðin meira að hverjum sjúklingi fyrir sig til pess að hámarka áhrifin á krabbameinsfrumurnar og minnka áhrifin á heilbrigða vefi og par með líkurnar á síðkomnum fylgikvillum. Ísland mun vonandi áfram skipa sess meðal peirra pjóða par sem horfur barna með krabbamein eru hvað bestar.

\section{Pakkir}

Pakkir fá Elínborg Ólafsdóttir verkfræðingur hjá Krabbameinsskrá Íslands, Lárus Guðmundsson kerfisfræðingur, Kristleifur Kristjánsson læknir hjá Íslenskri erfðagreiningu og Ásta Bragadóttir læknir. Rannsóknin hlaut styrk úr Kristínarsjóði árið 2008.

\section{Heimildir}

1. Jemal A, Siegel R, Ward E, et al. Cancer statistics, 2006. CA Cancer J Clin 2006; 56: 106-30.

2. Ries LAG, Smith MA, Gurney JG. Cancer Incidence and Survival Among Children and Adolescents: United States SEER Program 1975-1995: National Cancer Institude (NCI) - Surveillance, Epidemiology, and End Results (SEER). 1999.

3. Óskarsson T, Jónsson ÓG, Kristinsson JR, Jónmundsson GK, Jónasson JG, Haraldsson Á. Krabbamein hjá börnum á Íslandi árin 1981-2006. Læknablaðið 2010; 96: 21-6.

4. StillerCA, Desandes E, DanonSE, etal.Cancerincidence and survival in European adolescents (1978-1997). Report from the Automated Childhood Cancer Information System project. Eur J Cancer 2006; 42: 2006-18.

5. Felix CA, Lange BJ, Chessells JM. Pediatric Acute Lymphoblastic Leukemia: Challenges and Controversies in 2000. Hematology Am Soc Hematol Educ Program 2000: 285-302.

6. Gatta G, Capocaccia R, Coleman MP, Ries LA, Berrino F. Childhood cancer survival in Europe and the United States. Cancer 2002; 95: 1767-72.
7. Gatta G, Capocaccia R, Stiller C, Kaatsch P, Berrino F, Terenziani M. Childhood Cancer Survival Trends in Europe: A EUROCARE Working Group Study. J Clin Oncol 2005; 23: 3742-51.

8. Ries LAG, Eisner MP, Kosary CL, eds. Cancer Statistics Review, 1975-2002, SEER National Cancer Institute. http://seer.cancer.gov/csr/1975_2002/. 2005.

9. Lanzkowsky P. Manual of Pediatric Hematology and Oncology. Elsevier Academic Press, Burlington, 4. útg. 2005

10. HamreMR,WilliamsJ,ChubaP,BhambhaniK, Ravindranath Y, Severson RK. Early deaths in childhood cancer. Med Pediatr Oncol 2000; 34: 343-7.

11. Pastore G, Viscomi S, Mosso ML, et al. Early deaths from childhood cancer. A report from the Childhood Cancer Registry of Piedmont, Italy, 1967-1998. Eur J Pediatrics 2004; 163: 313-9.

12. Christensen MS, Heyman M, Möttönen M, et al. Treatmentrelated death in childhood acute lymphoblastic leukaemia in the Nordic countries: 1992-2001. Brit J Haematol 2005; 131: 50-8.

13. Diller L, Chow EJ, Gurney JG, et al. Chronic Disease in the Childhood Cancer Survivor Study Cohort: A Review of Published Findings. J Clin Oncol 2009; 27: 2339-55.

14. Hólm H, Jónsson ÓG, Pórsson ÁV, et al. Greining, árangur meðferðar og síðkomnar aukaverkanir æxla í miðtaugakerfi í æsku. Læknablaðið 2002; 88: 21-7.

15. Kristinsson VH, Kristinsson JR, Jónmundsson GK, Jónsson ÓG, Pórsson ÁV, Haraldsson Á. Síðkomnar og langvinnar aukaverkanir eftir hvítblæðismeðferð í æsku. Læknablaðið 2002; 88: 13-8.

16. Olsen JH, Moller T, Anderson H, et al. Lifelong Cancer Incidence in 47697 Patients Treated for Childhood Cancer in the Nordic Countries. J Natl Cancer Inst 2009; 101: 80613.

17. Dickerman JD. The Late Effects of Childhood Cancer Therapy. Pediatrics 2007; 119: 554-68.

18. Bhatia S, Sklar C. Second cancers in survivors of childhood cancer. Nature Rev Cancer 2002; 2: 124-32.

19. Meadow AT, Friedman DL, Neglia JP, et al. Second neoplasms in survivors of childhood cancer: findings from the Childhood Cancer Survivor Study cohort. J Clin Oncol 2009; 14: 2356-62.

20. Inskip PD, Curtis RE. New malignancies following childhood cancer in the United States, 1973-2002. Int J Cancer 2007; 121: 2233-40.

21. Rihani R, Bazzeh F, Faqih N, Sultan I. Secondary hematopoietic malignancies in survivors of childhood cancer. Cancer 2010; 116: 4385-94.

22. Steliarova-Foucher E, Stiller C, Lacour B, P K. International Classification of Childhood Cancer, third edition. Cancer 2005; 103: 1457-67.

23. Magnani C, Pastore G, Coebergh JW, Viscomi S, Spix C, Steliarova-Foucher E. Trends in survival after childhood cancer in Europe, 1978-1997: Report from the Automated Childhood Cancer Information System project (ACCIS). Eur J Cancer 2006; 42: 1981-2005.

24. Jónasson JG, Tryggvadóttir L, ritstj. Krabbamein á Íslandi - Upplýsingar úr Krabbameinsskrá fyrir tímabilið 19572006. Krabbameinsfélagið, Reykjavík 2008.

25. Nathan GD, Orkin SH, Look T, Ginsburg D. Nathan and Oski's Hematology of Infancy and Childhood. Saunders, Philadelphia, 6. útg. 2003.

26. Barnard DR, Lange B, Alonzo TA, et al. Acute myeloid leukemia and myelodysplastic syndrome in children treated for cancer: comparison with primary presentation. Blood 2002; 100: 427-34.

27. Voute PA, Barrett A, Stevens MCG, Caron HN Cancer in Children: Clinical Management. Oxford University Press, New York, 5. útg. 2005.

28. Kyrnetskiy EE, Kun LE, Boop FA, Sanford RA, Khan RB. Types, causes, and outcome of intracranial hemorrhage in children with cancer. J Neurosurg 2005; 102:31-5. 


\section{Survival and causes of death in children diagnosed with cancer in Iceland 1981-2006}

Objective: Of children diagnosed with cancer, approximately one fourth die of the disease or disease related complications. The aim of this study was to investigate survival and causes of death in children with cancer in Iceland.

Methods: This study is retrospective; population based and includes all children, less than 18 years of age, diagnosed with cancer in Iceland from 1981 to 2006. Information was extracted from the Icelandic Cancer Registry, patients hospital records and data from Statistics Iceland.

Results: Of 279 children diagnosed with cancer in the research period 215 were alive at the end of 2008 . The overall 5-year survival was $81.2 \%$ and 10 -year survival was
$76.7 \%$. There was not a significant survival difference with respect to age at diagnosis, year of diagnosis, gender or geographical residence. The small cohort size could be the explanation. Eleven individuals developed secondary neoplasm, eight of whom died. Sixteen of the 64 nonsurvivors were treated with curative intent until death, 12 of them died of therapy related complications.

Conclusions: Survival rate in childhood cancer in Iceland is comparable to other Western countries. As previously reported, prognosis of patients with secondary neoplasm is unfavorable. Therapy related complications are the most common cause of death in patients treated with curative intent.

Óskarsson T, Jónsson ÓG, Kristinsson JR, Jónmundsson GK, Jónasson JG, Haraldsson A.

Survival and causes of death in children diagnosed with cancer in Iceland 1981-2006. Icel Med J 2010; 96: 675-80

Key words: childhood cancer, epidemiology, survival.

Correspondence: Ásgeir Haraldsson, asgeir@landspitali.is

Barst: 14. apríl 2010, - sampykkt til birtingar: 3. október 2010 Hagsmunatengsl: Engin 